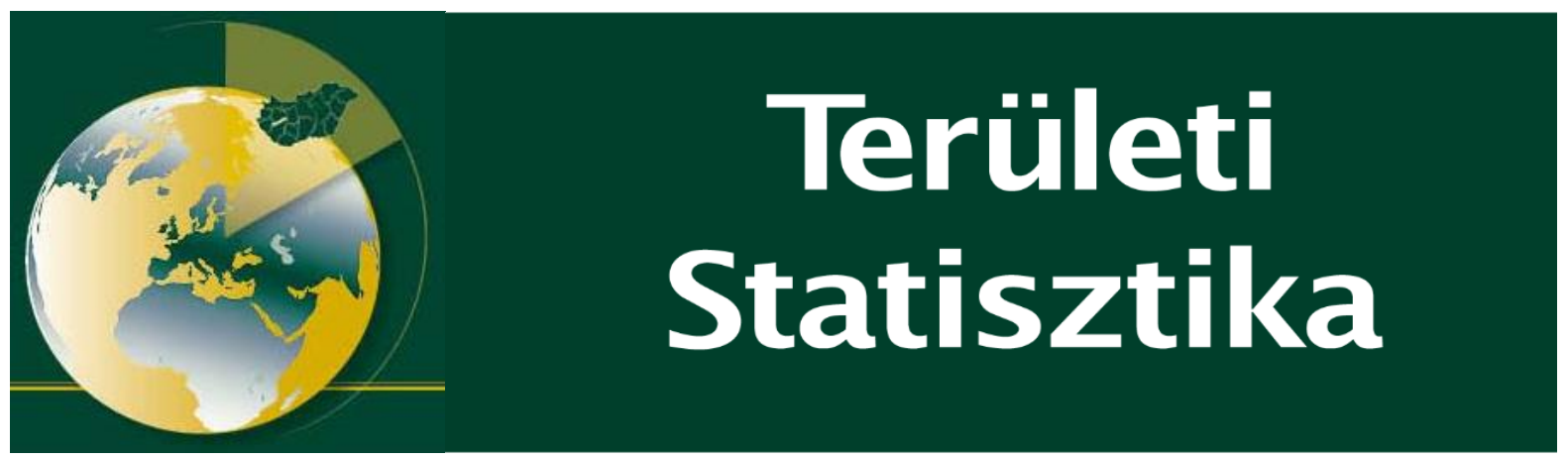

Közzététel: 2018. szeptember 28.

A tanulmány címe:

\title{
Az Airbnb szálláskínálatának jellemzői a megyei jogú városokban
} Szerzők:

Dudás Gábor, MTA KRTK RKI ATO Békéscsabai Csoport E-mail: dudasgabor5@gmail.com Kovalcsik Tamás, Szegedi Tudományegyetem, Gazdaság- és Társadalomföldrajz Tanszék

E-mail: kovalcsik.tamas@geo.u-szeged.hu

Boros Lajos, Szegedi Tudományegyetem, Gazdaság- és Társadalomföldrajz Tanszék E-mail: borosl@geo.u-szeged.hu

Kovalcsik Balázs, PROLAN Irányítástechnikai Zrt. E-mail: kobalaz07@gmail.com

Vida György, Szegedi Tudományegyetem, Gazdaság- és Társadalomföldrajz Tanszék

E-mail: vidagy@geo.u-szeged.hu

https://doi.org/10.15196/TS580502

Az alábbi feltételek érvényesek minden, a Központi Statisztikai Hivatal (a továbbiakban: KSH) Területi Statisztika c. folyóiratában (a továbbiakban: Folyóirat) megjelenó tanulmányra. Felbasználó a tanulmány, vagy annak részei felbasználásával egyidejúleg tudomásul veszi a jelen dokumentumban foglalt felbasználási feltételeket, és azokat magára nézve kötelezönek fogadja el. Tudomásul veszi, bogy a jelen feltételek megszegéséböl eredö valamennyi kárért felelösséggel tartozik.

1) A jogszabályi tartalom kivételével a tanulmányok a szerzői jogról szóló 1999. évi LXXVI. törvény (Szjt.) szerint szerzői münek minősülnek. A szerzői jog jogosultja a KSH.

2) A KSH földrajzi és időbeli korlátozás nélküli, nem kizárólagos, nem átadható, térítésmentes felhasználási jogot biztosít a Felhasználó részére a tanulmány vonatkozásában. 3) A felhasználási jog keretében a Felhasználó jogosult a tanulmány:

a) oktatási és kutatási célú felhasználására (nyilvánosságra hozatalára és továbbítására a

4. pontban foglalt kivétellel) a Folyóirat és a szerző(k) feltüntetésével;

b) tartalmáról összefoglaló készítésére az írott és az elektronikus médiában a Folyóirat

és a szerző(k) feltüntetésével;

c) részletének idézésére - az átvevő mű jellege és célja által indokolt terjedelemben és az eredetihez híven - a forrás, valamint az ott megjelölt szerző $(\mathrm{k})$ megnevezésével.

4) A Felhasználó nem jogosult a tanulmány továbbértékesítésére, haszonszerzési célú felhasználására. Ez a korlátozás nem érinti a tanulmány felhasználásával előállított, de az Szjt. szerint önálló szerzői műnek minősülő mű ilyen célú felhasználását.

5) A tanulmány átdolgozása, újra publikálása tilos.

6) A 3. a)-c.) pontban foglaltak alapján a Folyóiratot és a szerző(ke)t az alábbiak szerint kell feltüntetni:

„Forrás: Területi Statisztika c. folyóirat 58. évfolyam 5. számában megjelent, Dudás Gábor - Kovalcsik Tamás - Boros Lajos - Kovalcsik Balázs - Vida György által írt Az Airbnb szálláskínálatának jellemzôi a megyei jogú városokban c. tanulmány (link csatolása)"”

7) A Folyóiratban megjelenő tanulmányok kutatói véleményeket tükröznek, amelyek nem esnek szükségképpen egybe a KSH, vagy a szerzők által képviselt intézmények hivatalos álláspontjával. 


\section{Az Airbnb szálláskínálatának jellemzöi a megyei jogú városokban}

\section{Characteristics of Airbnb Accommodation Offers in Cities with County's Rights}

Dudás Gábor MTA KRTK RKI ATO

Békéscsabai Csoport

E-mail: dudasgabor5@gmail.com

Kovalcsik Tamás

Szegedi Tudományegyetem, Gazdaság- és Társadalomföldrajz

Tanszék

E-mail:

kovalcsik.tamas@geo.u-szeged.hu

\section{Boros Lajos}

Szegedi Tudományegyetem, Gazdaság- és Társadalomföldrajz

Tanszék

E-mail: borosl@geo.u-szeged.hu

Kovalcsik Balázs

PROLAN Irányítástechnikai Zrt.

E-mail:kobalaz07@gmail.com

Vida György

Szegedi Tudományegyetem, Gazdaság- és Társadalomföldrajz

Tanszék

E-mail: vidagy@geo.u-szeged.hu

Kulcsszavak:

sharing economy,

közösségi szállásadás, Airbnb,

rövid távú szállásadás,

P2P-szállásadó oldal, szállodai ár
Az infokommunikációs technológiák világgazdaságra gyakorolt hatásának egyik megnyilvánulása a megosztáson alapuló, azaz a közösségi gazdaság (sharing economy) kialakulása és térnyerése. Ennek egyik jelentős piaci szereplője az Airbnb, egy olyan szállásmegosztó oldal, ami hétköznapi emberek számára is lehetővé teszi, hogy megosszák egymással kihasználatlan ingatlankapacitásaikat. Napjainkban az Airbnb mind a piaci értékét, mind az oldalon kínált szállások számát tekintve jelentősen felülmúlja a nagy szállodaláncokét, és a világ 191 országában, több mint 81 ezer városban van jelen, továbbá az általa kínált szállások száma meghaladja az ötmilliót. Ezek alapján nemcsak globális szinten, de magyarországi viszonylatban is versenytársa a hagyományos szállásadó szektornak.

A tanulmány célja, hogy a korábbi, elsősorban Budapestre fókuszáló Airbnb-kutatásokkal szemben a megyei jogú városokban vizsgálja a magyarországi közösségi (P2P-) szállásadás árait, és azokat összehasonlítsa a kereskedelmi szálláshelyekével. A kutatás eredményei azt mutatják, hogy ezen városok Airbnbszálláskínálatának volumene jelentôsen elmarad a fővárosétól, azonban mind a nemzetközi, mind a budapesti trendek érvényesülnek, továbbá az Airbnb-szállásárak a megyei jogú városokban is versenyképesek a hagyományos szállásadás áraival, sőt a legtöbb esetben ezen az oldalon olcsóbban foglalhatunk szállást. 
The widely known effects of the info-communication technologies are that they have a significant impact on the world economy and one of these manifestations is the so-called "sharing economy". One of the key players of the sharing economy initiatives is Airbnb; an accommodation sharing platform that enables ordinary people to share their idle accommodation capacities. The importance of Airbnb is well illustrated by the fact that nowadays Airbnb outperforms the great hotel chains both in market value and number of accommodations offered. Moreover, it is present in more than 81000 cities in 191 counties and the number of accommodations offered on the platform exceeds 5 million. Thus, the platform became one of the most important players of the tourism industry not only at a global level but in Hungary as well, forming a serious competitor for the traditional accommodation sector.

The main aim of the study is to focus not primarily on Budapest but on a regional level and analyse short-term accommodation rental market in Hungarian cities with county rights and compare the prices of Airbnb listings and traditional accommodations. The results show, that the Airbnb supply is considerably lower than in Budapest, however, both

Keywords: the international and Budapest trends prevail in sharing economy, Airbnb, these cities. Moreover, it is also confirmed, that short-term accommodation Airbnb prices are competitive with hotel prices and rental, P2P accommodation in most of the cases Airbnb outperforms traditional platform, hotel price accommodation providers in offering lower prices.

Beküldve: 2018. július 17.

Elfogadva: 2018. augusztus 14.

\section{Bevezetés}

Naponta emberek tízezrei döntenek úgy, hogy nem a hagyományos szállásadásban - például szállodákban, panziókban - szállnak meg, hanem inkább ismeretlenek lakóhelyét veszik igénybe, amit a peer-to-peer (P2P) ${ }^{1}$ elven múködő online szállás-

${ }^{1}$ Az informatikai hálózat végpontjai közvetlenül egymással kommunikálnak, központi kitüntetett csomópont nélkül (Pluhár 2017).

Területi Statisztika, 2018, 58(5): 462-488; DOI: 10.15196/TS580502 
megosztó oldalakon - például Airbnb, Couchsurfing, HomeAway - találtak. Ez a folyamat egy nagy gazdasági-technológiai jelenség, a közösségi gazdaság (sharing

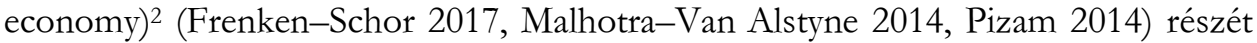
képezi, ami az elmúlt évtizedben rendkívül gyorsan nőtt, és meghatározó gazdasági jelentőségúvé vált (Sundararajan 2014, Teubner et al. 2016), megváltoztatva az emberek fogyasztáshoz, utazáshoz és tulajdonláshoz való hozzáállását (Bucher et al. 2016). A jelenség - azaz a kihasználatlan, nélkülözhető erőforrások megosztása másokkal - önmagában nem új keletư, azonban a világháló felgyorsítja annak mindennapi életünkbe való beépülését, és lehetővé teszi a felhasználók számára (BálintTrócsányi 2016), hogy a termékek és a szolgáltatások birtoklása helyett a fogyasztók egyre inkább azok megosztása és lízingelése felé forduljanak (Matzler et al. 2015). Így az emberek a tulajdonukban lévő eszközöket - például lakás, autó, kerékpár, szerszámok és egyéb hétköznapi eszközök -, szakértelmüket, idejüket teszik elérhetővé/hozzáférhetôvé mások számára különböző online oldalakon keresztül (Botsman-Rogers 2011, Bucher et al. 2016, Gansky 2010), akik csak az ideiglenes hozzáférésért fizetnek (Goudin 2016). Ezek alapján a közösségi gazdaság számos területen hat a fogyasztási szerkezetre, az árakra, valamint egyre nagyobb kihívások és verseny elé állítja a hagyományos piaci szereplőket is (Boros-Dudás 2017). Napjainkban az európai emberek 70, az egyesült államokbeliek 72\%-a érintett valamilyen közösségi gazdasághoz köthető tevékenységben (Murillo et al. 2017). Piaci súlyát jól mutatja, hogy míg a PricewaterhouseCoopers becslése alapján az 5 fó szektorba (közösségi finanszírozás és P2P-hitelezés, online távmunka, P2P-lakásmegosztás, -autómegosztás, online zene- és videóstreamelés) tartozó vállalatok 2013-ban 15 milliárd USD jövedelemre tettek szert, addig becslések szerint ez a szám 2025-ben elérheti a 335 milliárdot (PWC 2015). E globális folyamat részeként a P2P-szállásmegosztó oldalak is erőteljesen nőttek, és a közösségi gazdaság egyik fontos részterületévé váltak (Pizam 2014, Teubner et al. 2016).

Hazánkban gyakran keveredik a P2P- és a közösségi szállásadás fogalma, aminek az az oka, hogy az Airbnb vagy a Courchsurfing egyaránt a közösségi gazdaságnak nevezett jelenség része. Ugyanakkor a magyar fogalomhasználat és a szabályozás szerint a közösségi szálláshely egy létező fogalom: „kizárólag szálláshely-szolgáltatás folytatás céljából létesített szálláshelytípus, amelyben az egy szobában található ágyak külön-külön is hasznosításra kerülnek, s ahol az e célra hasznosított szobák száma legalább hat, az ágyak száma legalább tizenegy” (239/2009. (X. 20.) Korm. rendelet). Így tanulmányunkban a P2P-szállásadást, illetve szálláshely-meghatározást használtuk. A kereskedelmi szállásadás vizsgálata során a szállodákra és a panziókra fóku-

2 A sharing economy értelmezésére számos tanulmány született (Buda-Lehota 2017, Frenken 2017, MunozCohen 2017, Schor 2014, Stephany 2015), azonban a tanulmányunkban mi a Rachel Botsman (2015) által definiált formában értelmezzük és használjuk, miszerint a sharing economy (közösségi gazdaság) egy olyan „gazdasági rendszer, amely a kihasználatlan eszközök vagy szolgáltatások megosztására épül, ingyen vagy pénzügyi ellenszolgáltatásért cserébe, közvetlenül magánszemélyektôl’.

Területi Statisztika, 2018, 58(5): 462-488; DOI: 10.15196/TS580502 
száltunk (bár a hivatkozott rendelet alapján a kereskedelmi szálláshelyek ennél szélesebb kört jelölnek), szembe állítva az Airbnb-vel ezeket „hagyományos” szállásadóknak nevezzük.

A P2P-szállásadás - elsősorban az Airbnb - megerősödésével a közösségi gazdaság körébe tartozó szállásadás jelentős piaci részesedésre tett szert a „hagyományos” szállásadással (elsősorban a szállodákkal, panziókkal) szemben, nemcsak globálisan, hanem Magyarországon is (Boros et al. 2018). Ezzel összhangban a kutatók is fokozottan érdeklődnek az Airbnb-vel kapcsolatban, azonban a P2P-szállásadást vizsgáló tanulmányok többsége olyan fôvárosokra/nagyvárosokra fókuszál, mint például New York (Alvarado et al. 2016, Cox 2017, Cox-Slee 2016, Dudás et al. 2017c), Barcelona (Gutiérrez et al. 2017), London (Quattrone et al. 2016), Varsó (Gyódi 2018) vagy Bécs (Gunter-Önder 2017), ugyanis a legtöbb Airbnb a nagyvárosokban található. Emellett az Airbnb helyzetét globális szinten (Ke 2017, Nowak et al. 2015), országos szinten (Choi et al. 2015, Kljucnikov et al. 2018) vagy országok között (Abdar-Yen 2017) vizsgáló tanulmányok száma azonban igen kevés, és döntően e szállásmegosztó oldal kínálatának, keresletének térbeli eloszlásával foglalkozik. Ezt szélesíti Adamiak (2018) kutatása, aki Európában a 100 ezer főnél népesebb városok Airbnb-kínálatát vizsgálta, azonban a településhierarchia alacsonyabb szintjeire még nem végeztek a témában átfogó kutatásokat.

Az előzőekkel összhangban, fontosnak tartjuk a következők vizsgálatát: hol találhatóak a P2P-szálláshelyek Magyarországon, milyen folyamatok befolyásolják az elterjedésüket, hogyan hatnak a hagyományos szállásadásra a településhierarchia különböző szintjein. A magyar P2P-szállásadáshoz kapcsolódó folyamatok vizsgálatának középpontjában Budapest áll (Boros et al. 2018, Dudás et al. 2016, 2017a, 2017b, Jancsik et al. 2018, Karakasné Morvay 2017, Ranchordás et al. 2016, Smith et al. 2017). E tanulmányok elsősorban az Airbnb-listázások (azaz Airbnb oldalán meghirdetett szálláshelyek) területi jellemzőivel (Boros et al. 2018, Dudás et al. 2016, 2017a, 2017b), a fôvárosi szálláshelypiac változásaival (Jancsik et al. 2018), valamint a múködési körülményeket érintô szabályozási kérdésekkel (Jancsik et al. 2018, Ranchordás et al. 2016, Smith et al. 2017) foglalkoznak, de készült esettanulmány Pécs Airbnb-piacáról is (Bálint-Magyar-Papp 2016). Tanulmányunk célja, hogy a korábbi kutatásokkal ellentétben a településhierarchia alacsonyabb szintjén, azaz a megyei jogú városokban vizsgáljuk a P2P-szállásadás helyzetét, elterjedését, és öszszehasonlítsuk az Airbnb- és a kereskedelmi szálláshelyek árait. A kereskedelmi szálláshelyek árai a Trivago online metakereső oldal által az adott szállodára vonatkozóan feltüntetett legolcsóbb szállásárakat jelentik. Ez egy személyre vonatkozik, és nem tartalmazza a kiegészítő szolgáltatásokért fizetendő árat, valamint a helyi idegenforgalmi adót. Ezeken a tételeken kívül azonban a megjelenített ár a teljes fizetendő költség, azaz nem járul hozzá egyéb (például foglalási vagy takarítási) díj. A megyei jogú városok kiválasztását a hasonló településhierarchia-szintre vonatkozó vizsgálatok alacsony száma indokolta. Az Airbnb kifejezetten nagyvárosi jelenség,

Területi Statisztika, 2018, 58(5): 462-488; DOI: 10.15196/TS580502 
így kutatásunkkal hozzájárulhatunk annak bemutatásához, hogy milyen mértékben és hogyan terjedt el a P2P-szállásadás a hazai településhálózatban. Mivel elemzésünket nem szándékoztuk a 100 ezer fó feletti városokra vagy a regionális központokra korlátozni, ezért a megyei jogú városok mellett döntöttünk. Természetesen e települések nem alkotnak homogén csoportot, lakosságszámuk és társadalmi-gazdasági szerepkörük miatt a magyar településhálózat fontos elemei, így belső térfolyamataik vizsgálata, összehasonlítása hasznos lehet tudományos és gyakorlati szempontból is. Azt is fontos kiemelni, hogy a megyei jogú városok természetesen nem a leglátogatottabb, vagy a legnagyobb idegenforgalmiadó-bevételt elkönyvelő városok (M. Barna-Papp 2017), viszont lakásállományuk mérete révén nagyobb valószínűséggel találunk ezekben nagyszámú, a P2P-szállásadás területén hasznosítható ingatlanokat.

A tanulmány első felében áttekintjük az Airbnb-vel kapcsolatos szakirodalmat, majd ismertetjük a kutatásunknál alkalmazott módszereket. A tanulmány második felében bemutatjuk a magyarországi szállásadás keresleti és kínálati oldalát, továbbá az Airbnb szerepét a megyei jogú városokban. Az általános jellemzők és a területi eloszlás elemzését követően összefoglaljuk eredményeinket, valamint felvázoljuk a kutatás további irányait.

\section{Irodalmi áttekintés}

A szállások magánszemélyek közötti, informális alapon történő kiadása már évszázadok óta létező jelenség (Guttentag 2013, Guttentag et al. 2017), Magyarországon is több évtizedes múltra tekint vissza, említsük például a közismert "Zimmer Frei” gyakorlatot (MSZÉSZ 2015). Ennek az új típusú, P2P-elven múködő szállásformának azonban a globális léptékú elterjedését a világháló, a Web 2.0, valamint a mobiltechnológiák fejlődése tette lehetővé (Gutiérrez et al. 2017). A P2P-szállásadó oldalak között az Airbnb a piacvezető és a legjobban dokumentált (Oskam-Boswijk 2016), amely a 2008-as alapítása óta rendkívül gyors ütemben nőtt, és globális szinten is elterjedt (Ke 2017). Napjainkra mind a piaci értékét, mind pedig az oldalakon kínált szállások számát tekintetve jelentősen felülmúlta a nagy szállodaláncokat (Guttentag 2013, Oskam-Boswijk 2016), és a világ 191 országában, 81 ezer városban van jelen, továbbá az oldalon kínált szállások száma meghaladja az ötmilliót (Airbnb 2018).

A hagyományos szállásadó szektorral ellentétben az olyan oldalak, mint az Airbnb lehetôvé teszik az egyének számára, hogy mikrovállalkozók legyenek, és mint szállásadók a lakásukat kiadják turistáknak vagy üzleti utazóknak (Sundararajan 2014). A lényege abban rejlik, hogy a szállásadók - az Airbnb oldalán keresztül bérbe adhatják a turistáknak a kihasználatlan tereiket/ingatlanjaikat néhány napra, hétre vagy hónapra, annak függvényében, hogy a kiadott szállás milyen típusú és hol található, így a szállásadók jelentős jövedelemre tehetnek szert (Jung et al. 2016, Teubner et al. 2016). Az Airbnb lehetőséget teremt egy teljes lakás vagy akár egyet-

Területi Statisztika, 2018, 58(5): 462-488; DOI: 10.15196/TS580502 
len szoba meghirdetésére is, azaz jóval rugalmasabb és szélesebb kínálatot biztosít, mint a hotelláncok (Dudás et al. 2016).

A közösségi gazdaság széles körú pozitív gazdasági hatásai ellenére számos vitát, szabályozási kihívást és politikai küzdelmet generál világszerte. Ennek következtében a P2P-szállásadás - különösen az Airbnb - is jelentős médiafigyelmet kapott az elmúlt években (Dudás et al. 2017c), továbbá mind a kutatók, mind a turizmuselemzôk érdeklődését felkeltette. Míg az Airbnb hatásairól szóló tanulmányok egy része az oldalak működéséhez kapcsolható, valamint az online értékelések és visszajelzések megbízhatóságára fókuszál (Ert et al. 2016, Zervas et al. 2015), addig más része a P2P-szállásszolgáltatás múködési területeivel, az ahhoz kapcsolható jogi, szabályozási és adózási kérdésekkel foglalkozik (Guttentag 2013, Hajibaba-Dolnicar 2017, Jefferson-Jones 2015, Kaplan-Nadler 2015, Ranchordás et al. 2016). További tanulmányok társadalmi és pszichológiai szempontból vizsgálták a közösségi szállásmegosztás motiváló tényezőit, elsősorban a fogyasztók (Guttentag 2013, Guttentag et al. 2017, Möhlmann 2015, Tussyadiah-Pesonen 2016) és a szállásadók (Ert et al. 2016, Karlsson-Dolnicar 2016) oldaláról. Számos kutatás foglalkozott a közösségi gazdaság gazdasági (Fang et al. 2016, Gutt-Hermann 2015, Kakar et al. 2016), valamint az Airbnb lakáspiacra gyakorolt hatásaival is. Kimutatták, hogy az Airbnb terjedése növeli a lakóingatlanok árait és az albérletek bérleti dijait is (Cox-Slee 2016, Delgado-Medrano-Lyon 2016, Sabatini 2015, Samaan 2015, Waters-Bach 2016), ily módon egyfajta dzsentrifikációs vagy diszkriminációs eszközként is funkcionálhat (Edelman et al. 2017), mivel támogatja az alacsony jövedelmú és hátrányos helyzetú lakosok kirekesztését bizonyos városrészekből (Cox 2017, Wachsmuth et al. 2018). Ez a veszély Budapesten is jelentkezik, hiszen a kiadott lakások többsége nem felesleges kapacitás, hanem befektetési céllal vásárolt ingatlan, vagy olyan lakás, amelyet korábban hosszabb távra adtak ki a tulajdonosaik, azonban a magasabb haszon reményében a rövid távú kiadásra, azaz az Airbnb-re váltottak (Boros-Dudás 2017). Így sok esetben nem a meglévő, kihasználatlan kapacitások kiadásával, hanem vállalkozásjellegû tevékenységgel foglalkoznak.

Az Airbnb az elmúlt néhány év folyamán dinamikusan nőtt, azonban a hagyományos szállásadásra gyakorolt hatásairól megoszlanak a vélemények. Míg egyesek azon az állásponton vannak, hogy az Airbnb valós fenyegetést jelent a hagyományos szállásadóknak, addig mások megkérdőjelezik az Airbnb hatásait, és azt hangsúlyozzák, hogy az Airbnb szállodaszektorra gyakorolt hatása elhanyagolható mértékú, ugyanis attól teljesen eltérô, alacsonyabb színvonalú szolgáltatást kínál, ráadásul egy teljesen más piaci szegmensnek, ami nem vonzó (a legtöbb bevételt hozó) az üzleti utazó számára (Guttentag-Smith 2017). Ennek nyomán számos tanulmány foglalkozott a szállásmegosztó oldalak hatásainak bemutatásával, azonban megállapításaik és következtetéseik vegyesek (Xie-Kwok 2017). Míg egy részük az Airbnb hotelszektorra gyakorolt negatív hatásait (például Corsun et al. 2016, HVS 2015, Neeser 2015, Zervas et al. 2017) emeli ki, addig közel ugyanennyi vizsgálat szerint e hatások

Területi Statisztika, 2018, 58(5): 462-488; DOI: 10.15196/TS580502 
elhanyagolhatóak (például Alvarado et al. 2016, Choi et al. 2015, Haywood et al. 2016).

Az Airbnb és a hotelek kapcsolatát is számos kontextusban vizsgálták már. Zervas és szerzőtársai (2017) az Airbnb-listázások (azaz az Airbnb oldalán meghirdetett szálláshelyek) számának növekedése és a hotelek bevételei közötti kapcsolatot elemezték Texasban. Arra a következtetésre jutottak, hogy a listázások számának 10\%-os növekedése 0,37\%-kal csökkenti a hotelek bevételeit. A szerzők arra is felhívták a figyelmet, hogy ezek a hatások sokkal erôteljesebbek az olcsó szállodáknál, a független hoteleknél és a szállásadóknál. Hasonló vizsgálatot végzett Neeser (2015) a skandináv térségben. Eredményei azt mutatták, hogy az Airbnb negatívan hat a hotelszobák napi átlagáraira, azonban nem befolyásolja az egy szobára jutó szállásdíjbevételt. Ez arra enged következtetni, hogy a hotelek csökkentik áraikat annak érdekében, hogy fenn tudják tartani a kihasználtsági szintjüket. Ezzel szemben Choi és szerzôtársainak (2015) elemzése a koreai szállásadóknál azt állapította meg, hogy az Airbnb térnyerése nincs hatással a szállodák bevételeire. Lane és Woodworth (2016) az Egyesült Államok városainak hotel- és Airbnb-adatait vizsgálva azt állapították meg, hogy az Airbnb leginkább a csúcsidőszakokban korlátozza a hotelek magasabb árait, és fékezi a kínálat bővülését. Ugyanakkor Haywood és szerzôtársai (2016) manhattani szállodai és Airbnb-adatok alapján nem találtak egyértelmû bizonyítékot arra, hogy az Airbnb elvenné a vendégeket a hotelektől, viszont megnehezíti számukra a csúcsidőszakokban korábban jellemző felárak alkalmazását.

Az eddigiek alapján körvonalazódik, hogy nincs konszenzus arról, hogy milyen hatással van az Airbnb a hotelekre, hiszen a vizsgálat mintanagyságától és helyétôl függően eltérő megállapítások születtek, ugyanakkor a kutatások arra a következtetésre jutottak, hogy a P2P-szállásokat igénybe vevő emberek szállásválasztása során a fó motiváló tényező az Airbnb-szállások kedvezőbb ára volt, a hagyományos szállások áraival szemben (Guttentag 2013, Nowak et al. 2015, Tussyadiah 2015). A kedvező ár különösen a korlátozott erőforrásokkal rendelkező, de az infokommunikációs technológiát intenzíven használó fiatalok, valamint a több főre szállást kereső, árérzékeny családok számára teszi versenyképessé az Airbnb-t. Kutatásunk további részében megvizsgáltuk az Airbnb- és a hotelkínálat alakulását a magyarországi megyei jogú városokban, és összehasonlítottuk az árakat e két szállástípus között.

\section{A kutatás során alkalmazott módszerek}

A P2P- és a kereskedelmi szállásadás vizsgálata bonyolult feladat a hivatalos adatbázisok hiánya és hiányosságai, valamint a szürke- és feketegazdaság (be nem jelentett szállásadás) kiterjedtsége miatt (Dudás et al. 2016). Ennek alapján a kereskedelmi szállásadatokat a Központi Statisztikai Hivatal (KSH) honlapjáról és kiadványaiból szereztük be, azonban a P2P-szállásadatok megismeréséhez saját adatgyújtésre is

Területi Statisztika, 2018, 58(5): 462-488; DOI: 10.15196/TS580502 
szükségünk volt. Korszerú, internetes adatgyújtésen alapuló technikákat is alkalmaztunk (Pásztor et al. 2017). Az adatgyújtés hatékonyságának növelése érdekében az Airbnb hatásait vizsgáló nemzetközi kutatási gyakorlatok alapján (Gibbs et al. 2017, Horn-Merante 2017, Ke 2017, Teubner et al. 2017, Wegmann-Jiao 2017) automatizáltuk a folyamatot, és web scraping technológiával, számítógépes program segítségével az Airbnb-adatokat közvetlenül azok honlapjáról (www.airbnb.com) kérdeztük le, az elemzésre kiválasztott 23 megyei jogú városra. A program lényege, hogy az előre definiált paraméterek alapján felkeresi az adott honlapot, és a megadott irányelvek alapján egy adatbázisba menti az oldalon található adatokat, további elemzés céljára (Olmedilla et al. 2016). A kutatásunkhoz a következő adatokat gyújtöttük össze: (1) az Airbnb-szállások száma, típusa (teljes lakás, privát szoba, közös szoba) és földrajzi elhelyezkedése, (2) a szállások kapacitásadatai (férőhelyek, fürdőszobák, szobák száma), (3) a szállások ára, (4) az üzemeltetők száma, (5) az eltöltött vendégéjszakák utáni vélemények száma és azok értéke.

Annak érdekében, hogy az Airbnb-n kiadott szállások és a kereskedelmi szállások árait még pontosabban összehasonlíthassuk, a KSH hivatalos statisztikái mellett egy kiegészitő adatfelvételt is végeztünk a Trivago online metakereső oldal segítségével. E lekérdezés során hasonló eljárást alkalmaztunk, mint az Airbnb-adatok gyújtésénél, azonban meg kell említenünk, hogy nem a Trivago az egyetlen internetes kereső felület online szállásfoglalásra. Ilyenek még az online utazási oldalak (például booking.com, szállás.hu), az online utazási irodák (például Expedia, Orbitz), vagy további metakereső oldalak (például Skyscanner, Tripadvisor) is. Az összehasonlító lekérdezések során azonban a Trivago felülete bizonyult a leginkább felhasználóbarátnak, a webfelület információtartalma is megfelelő volt a számunkra, továbbá a választott keresőnk listázta az online utazási oldalak és az online utazási irodák ajánlatait is. Alkalmazott módszerünk előnye, hogy a hivatalos statisztikáknál részletesebben mutatta az árak alakulását (Pásztor et al. 2017), azonban fontos kiemelni, hogy éppen a nagy adatmennyiség és az árak dinamikus változása miatt az adatok kezelése, a hivatalos statisztikákkal való összevetése és a következtetések levonása fokozott körültekintést igényelt. A lekérdezések során a program az általunk megadott paraméterek alapján (például utazók száma, szállás típusa, szállás helye) automatikusan lekérdezte az adatokat 2018. áprilisra, és a feldolgozás érdekében mentette azokat egy adatbázisba. A P2P-, illetve a kereskedelmi szállásadatoknál 1 fó 1 éjszakára vonatkozó szállásköltségeit kérdeztük le. Az adatok lekérdezése, feldolgozása és adatbázisba rendezése után megszerkesztettük és elemeztük a diagramokat.

\section{A szálláskereslet és -kínálat alakulása - az Airbnb térnyerése}

Magyarországon a KSH adatai szerint a hagyományos szálláshelyeken regisztrált vendégéjszakák száma 2010 és 2017 között dinamikusan nőtt. 2017-ben a vendégforgalom megközelítette a 40 milliót, melynek 74,7\%-át a kereskedelmi, 20,7\%-át az

Területi Statisztika, 2018, 58(5): 462-488; DOI: 10.15196/TS580502 
üzleti célú egyéb (továbbiakban magánszálláshelyek), 4,6\%-át a nem üzleti célú szálláshelyeken regisztrálták. A vizsgált időszakban a hazánkban eltöltött külföldi és belföldi vendégéjszakák száma több mint 50\%-kal emelkedett, ami éves szinten a külföldi vendégéjszakáknál átlagosan 6,5, a belföldieknél 5,9\%-os bővülést jelentett. A magánszálláshelyek vendégéjszakáinak száma (külföldi és belföldi együtt) ennél nagyobb mértékben, 2,5-szeresére nőtt a vizsgált időszakban, és 2017-ben átlépte az évi 8 millió vendégéjszakát (1. ábra).

1. ábra

A vendégéjszakák számának alakulása a kereskedelmi és a magánszálláshelyeken

Number of tourism nights in public and private accommodation establishments in Hungary
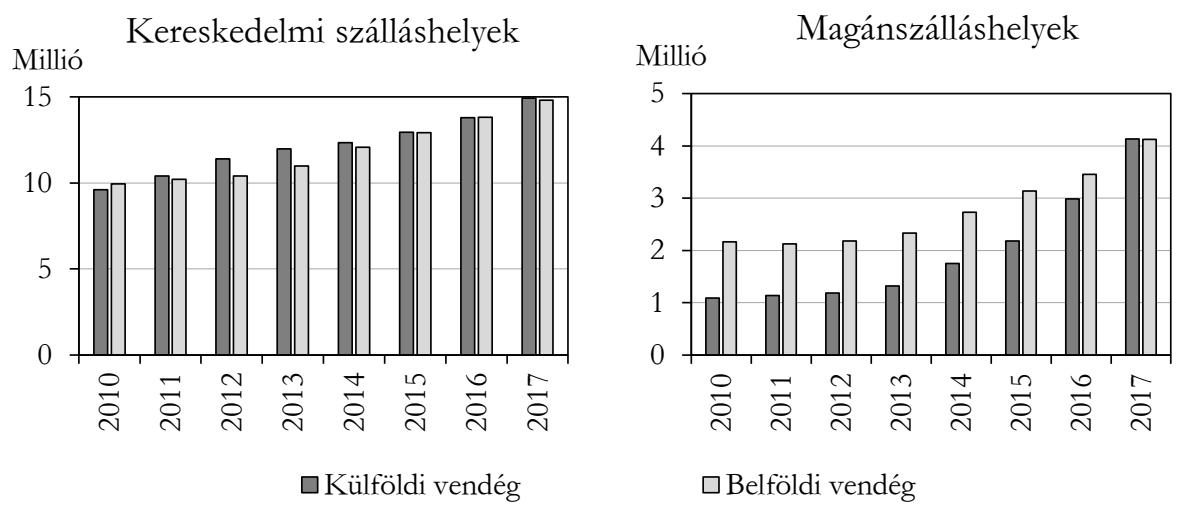

Forrás: KSH adatai alapján saját szerkesztés.

A KSH az Airbnb-n keresztül történő szálláskiadást a magánszálláshelyek kategóriába sorolja. A magánszálláshelyeken eltöltött vendégéjszakák száma országosan először 2013-ban nőtt jelentősebben, vélhetően az Airbnb is ekkor vált közismertté hazánkban. Ez a növekedés azonban Budapestre összpontosult, amit jól mutat a google keresőben a budapesti Airbnb-re indított keresések számának alakulása (2. ábra), továbbá a budapesti Airbnb-szállások számának jelentős emelkedése is (Boros et al. 2016). 2013-tól éves szinten átlagosan körülbelül 20\%-kal nőtt a magánszálláshelyeken eltöltött vendégéjszakák száma. Ugyanakkor fontos, hogy az Airbnbfelhasználók elsősorban a külföldi vendégéjszakák számában jelennek meg a statisztikákban, ami a belföldinél dinamikusabban nőtt 2013 és 2017 között. Míg 2013-ban a külföldi vendégéjszakák száma a magánszálláshelyeken csak $64 \%$-a volt a belföldinek, addig 2017-ben már a belföldinél több külföldi vendégéjszakát regisztráltak. 
2. ábra

A budapesti Airbnb-re indított keresések relatív gyakoriságának* alakulása Relative frequency* of search Airbnb in Budapest, 2013-2018 - The monthly values are displayed as a percentage of the highest value of the analysed period

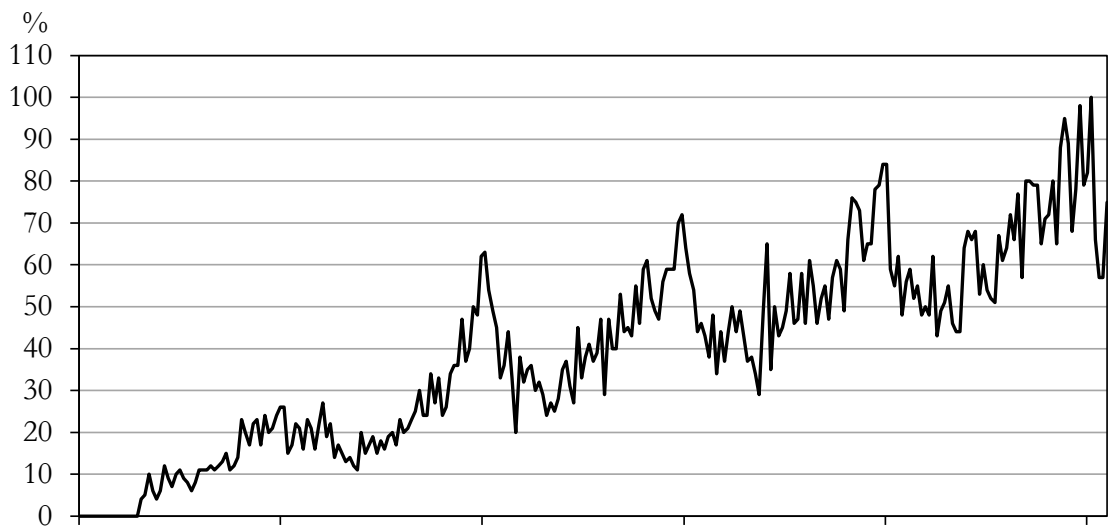

2013. augusztus 2014. augusztus 2015. augusztus 2016. augusztus 2017. augusztus 2018. augusztus

* Az adatok a vizsgált idôszakban mért legnagyobb érdeklődés százalékában adják meg a havi keresések számát. Forrás: Google Trends.

3. ábra

A férőhelyek számának alakulása a kereskedelmi és a magánszálláshelyeken Capacity of public and private accommodation establishments

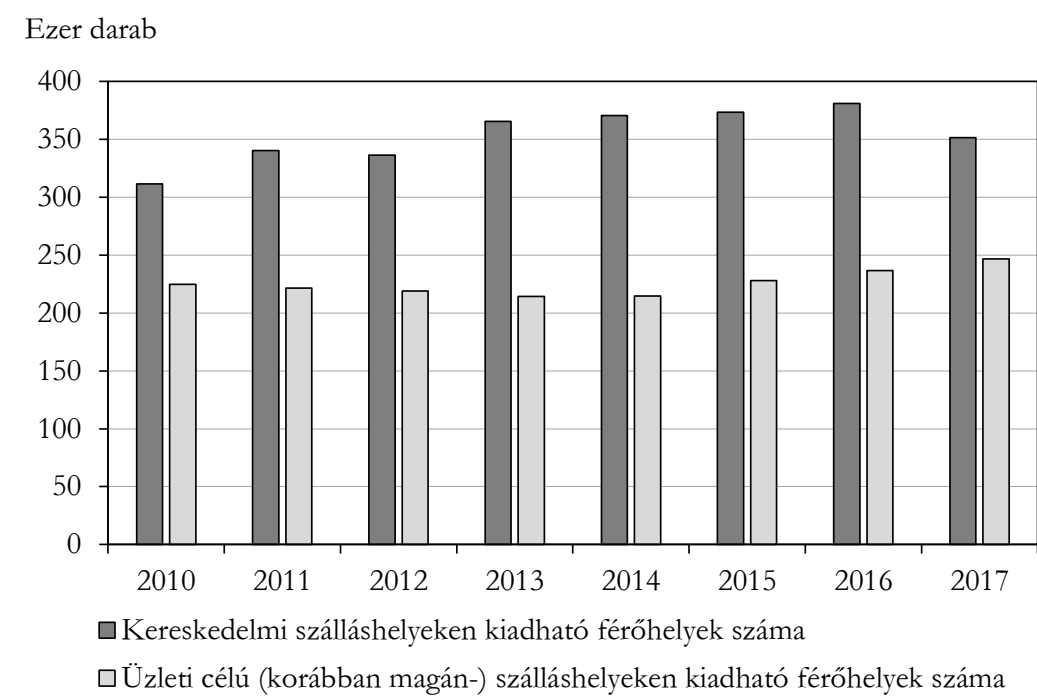

Forrás: KSH adatai alapján saját szerkesztés.

Területi Statisztika, 2018, 58(5): 462-488; DOI: 10.15196/TS580502 
A keresleti oldallal szemben a kínálati oldal szerényebben nőtt, sőt egyes években a kereskedelmi szálláshelyek férőhelyeinek száma még csökkent is (3. ábra). Míg a vizsgált időszakban a férőhelyek száma a kereskedelmi szálláshelyeken 12, addig a magánszálláshelyeken 9,7\%-kal nőtt. Ha az adatokat 2013-tól (az Airbnb széles körű elterjedésétől) vizsgáljuk, akkor a magánszálláshelyek férőhelyeinek száma több mint 15\%-kal nőtt, miközben a kereskedelmi szálláshelyeké 3,8\%-kal csökkent.

Az Airbnb térnyerését az is jól mutatja, hogy míg 2010-ben a magánlakásokban regisztrált külföldi vendégéjszakák száma a szállodákban regisztráltaknak a 34\%-át tette ki, addig 2017-ben már elérte a 82\%-át, amikor is a magánszálláshelyeken eltöltött külföldi vendégéjszakák száma meghaladta a 4 milliót. Ez a dinamikus növekedés azonban elsősorban a fővárosban összpontosult. A vizsgált időszakban Budapesten a magánszállásadók száma több mint 7-szeresére és az ezekben kínált féróhelyek száma közel 5-szörösére nőtt, szemben a megyei jogú városok mérsékeltebb növekedésével (1. táblázat).

1. táblázat

Az üzleti célú (korábban magán-) szálláshelyek kapacitása

Capacity of private accommodation establishments, 2010-2017

\begin{tabular}{c|c|c|c|c|c|c}
\hline \multirow{2}{*}{ Év } & \multicolumn{3}{|c|}{ Szálásadók száma, fő } & \multicolumn{3}{c}{ Férőhelyek száma, darab } \\
\cline { 2 - 7 } & országos & Budapest & $\begin{array}{c}\text { megyei jogú } \\
\text { városok }^{a}\end{array}$ & országos & Budapest & $\begin{array}{c}\text { megyei jogú } \\
\text { városok }^{\text {a }}\end{array}$ \\
\hline 2010 & 38307 & 1059 & 1112 & 224719 & 5992 & 7308 \\
2011 & 37129 & 1100 & 1088 & 221546 & 6671 & 7452 \\
2012 & 36249 & 1173 & 1187 & 219054 & 9739 & 8312 \\
2013 & 35636 & 1695 & 1203 & 214213 & 7586 & 8254 \\
2014 & 35166 & 2562 & 1270 & 214551 & 11869 & 8973 \\
2015 & 37237 & 4047 & 1345 & 228076 & 19808 & 9719 \\
2016 & 38292 & 5449 & 1530 & 236752 & 23059 & 10692 \\
2017 & 40996 & 7255 & 1812 & 246718 & 30039 & 12249
\end{tabular}

a) 2013 és 2017 között a megyei jogú városok adatai - adatvédelem miatt - Tatabánya nélkül szerepelnek.

Forrás: KSH adatai alapján saját szerkesztés.

Az említett koncentrációt támasztja alá a magánszálláshelyeken a külföldi vendégek vendégéjszakában mért vendégforgalmának alakulása is (2. táblázat). 2017-ben Budapesten regisztrálták a magánszálláshelyek külföldi vendégforgalmának több mint 62\%-át, és a külföldi vendégforgalom 2010 és 2017 között közel 20-szorosára nőtt. Ezzel szemben a megyei jogú városokban (de országos szinten is) a növekedés mértéke és üteme is kisebb volt. Míg 2010-ben 1112 magánszálláshelyen 7308 férőhelyet kínáltak a megyei jogú városokban, addig 2017-ben 1812 magánszálláshely, 12249 férőhellyel üzemelt (1. táblázat), ahol a külföldivendég-forgalom mindössze 4\%-a realizálódott. Fontos azonban megjegyezni, hogy a KSH statisztikái csak az

Területi Statisztika, 2018, 58(5): 462-488; DOI: 10.15196/TS580502 
önkormányzatoknál regisztrált szállásadókat és a náluk eltöltött vendégéjszakákat tartalmazzák, így a növekedés a regisztráltnál is nagyobb lehet, hiszen az Airbnb- $n$ keresztül történő szállásadás még napjainkban is döntően az informális szektorban történik. Erre a statisztikai anomáliára mutatott rá Jancsik és szerzőtársainak (2018) tanulmánya is, amelyben megállapították, hogy Budapesten sokkal több Airbnb-n kínált szállás van a KSH statisztikáiban szereplőnél. Ennek alapján indokolttá vált a megyei jogú városoknál is hasonló összehasonlítás elkészítése, ami összeveti az Airbnb-n keresztül kiadott magánszálláshelyek számát, árát és azok különböző szolgáltatásait a kereskedelmi szálláshelyekével, továbbá feltárja a vizsgált piaci szegmens aktuális helyzetét. A következő fejezetben ezzel foglalkozunk részletesen.

\section{Üzleti célú egyéb (korábban magán-) szálláshelyek külföldi vendégéjszakáinak száma}

Number of foreign tourism nights in private accommodation establishments

\begin{tabular}{c|c|c|c}
\hline Év & Országos & Budapest & Megyei jogú városoka) \\
\hline 2010 & 1086837 & 131587 & 27119 \\
2011 & 1137485 & 144983 & 35787 \\
2012 & 1187014 & 279908 & 47079 \\
2013 & 1323673 & 395146 & 59737 \\
2014 & 1752485 & 743457 & 82661 \\
2015 & 2181923 & 1106099 & 98374 \\
2016 & 2987170 & 1776045 & 131351 \\
2017 & 4135241 & 2583442 & 168268
\end{tabular}

a) 2013 és 2017 között a megyei jogú városok adatai - adatvédelem miatt - Tatabánya nélkül szerepelnek. Forrás: KSH adatai alapján saját szerkesztés.

\section{Az Airbnb kínálata a megyei jogú városokban}

\section{Általános jellemzők}

A kutatás során gyűjtött adatok a megyei jogú városok Airbnb kínálatát mutatják be 2018 áprilisában. A vizsgált hónapban a megyei jogú városokban 890 szállásadó nyújtott szolgáltatást, ami közel fele a KSH statisztikáiban szereplő magánszálláshelyeknek, és jelentősen elmarad a fóvárosi Airbnb-kínálattól is, ami körülbelül 9 ezer aktív szállást jelentett 2018 áprilisában (www.airdna.co). A szállásadó oldalon hirdetett szállások kapacitásadatait a szállodák adataival összehasonlítva megállapíthatjuk (3. táblázat), hogy az Airbnb-n hirdetettek száma meghaladja a kereskedelmi szálláshelyekét, azonban a kínált férőhelyek és a szobák száma messze elmarad a kereskedelmi szálláshelyek kínálatától, és a szállodák férőhelyeinek mindössze 14\%-át kínálják, így közel sem töltenek be olyan jelentős szerepet, mint Budapesten, ahol ez az arány $50 \%$ körüli.

Területi Statisztika, 2018, 58(5): 462-488; DOI: 10.15196/TS580502 
3. táblázat

A szálláskínálat jellemzői a megyei jogú városokban, 2018. április Basic data on capacity of accommodations in cities with county rights, April 2018

\begin{tabular}{|c|c|c|c|}
\hline \multirow{2}{*}{ Megnevezés } & Szálláshelyek & Férőhelyek & Szobák \\
\hline & \multicolumn{3}{|c|}{ száma } \\
\hline Airbnb & 890 & 3739 & 1440 \\
\hline Kereskedelmi szálláshelyek összesen & 562 & 41627 & 14788 \\
\hline Ebből szállodaa) & 212 & 20332 & 8540 \\
\hline
\end{tabular}

a) 2018 áprilisában a szállodák adatai - adatvédelem miatt - Dunaújváros, Kaposvár, Salgótarján, Szekszárd, Tatabánya és Zalaegerszeg nélkül szerepelnek.

Forrás: KSH adatai és egyéni adatgyűjtés alapján saját szerkesztés.

Az Airbnb szállástípus szerinti jellemzői a nemzetközi trendekhez is igazodnak (4. táblázat).

4. táblázat

Az Airbnb kínálata szállástípusonként a megyei jogú városokban, 2018. április Basic data on lodgings offered by Airbnb in cities with county rights by accommodation type, April 2018

\begin{tabular}{|c|c|c|c|c|}
\hline Jellemzők & Teljes lakás & Privát szoba & Közös szoba & Összesen \\
\hline Szálláshelyek száma & 628 & 255 & 7 & 890 \\
\hline & \multicolumn{4}{|c|}{ Ár, forint/éjszaka } \\
\hline Átlag & 13426 & 14028 & 5853 & 13539 \\
\hline Minimum & 2599 & 2246 & 2777 & 2246 \\
\hline \multirow[t]{2}{*}{ Maximum } & 160399 & 21615 & 12000 & 160399 \\
\hline & \multicolumn{4}{|c|}{ Férőhelyek száma, darab } \\
\hline Száma & 2869 & 839 & 31 & 3739 \\
\hline Átlag & 4,57 & 3,25 & 4,43 & 4,20 \\
\hline Minimum & 1 & 1 & 1 & 1 \\
\hline \multirow[t]{2}{*}{ Maximum } & 16 & 16 & 16 & 16 \\
\hline & \multicolumn{4}{|c|}{ Ágyak száma, darab } \\
\hline Átlag & 3,18 & 2,39 & 3,83 & 2,96 \\
\hline Minimum & 1 & 1 & 1 & 1 \\
\hline \multirow[t]{2}{*}{ Maximum } & 20 & 23 & 8 & 23 \\
\hline & \multicolumn{4}{|c|}{ Értékelések } \\
\hline Száma & 6256 & 1033 & 34 & 7323 \\
\hline Átlag & 9,96 & 4,17 & 4,86 & 8,23 \\
\hline Minimum & 0 & 0 & 0 & 0 \\
\hline Maximum & 154 & 49 & 22 & 154 \\
\hline Átlagérték & 4,83 & 4,61 & 5,00 & 4,81 \\
\hline
\end{tabular}

Forrás: egyéni adatgyűjtés alapján saját szerkesztés. 
A kínálatban a teljes lakások aránya 70,6, a privát szobáké a 28,6, a közös szobáké pedig $0,8 \%$. Az oldalon elérhető szállásokat átlagosan 13539 forintért lehet foglalni, azonban az árak széles sávban (2 246 és 160399 forint között) mozognak. A teljes lakásokban és a privát szobákban közel azonos áron - 13,5-14 ezer forintos átlagáron -, míg közös szobában átlagosan 5853 forintért szállhattunk meg 2018 áprilisában. Hangsúlyozni kell azonban, hogy az alacsony elemszám miatt a közös szobák szerepe és hatása nem számottevő, így a vizsgálat további részében eltekintünk tőlük. Az árak összevetésére a kétmintás t-próbát is alkalmaztunk a teljes lakások és a privát szobák között, és megállapítottuk, hogy a 883-as elemszám és szórásheterogenitás mellett az átlagárak statisztikailag szignifikánsan nem különböznek (t: -,423, sig: 0,673). Az Airbnb-férőhelyek megoszlásában még nagyobb a koncentráció, ugyanis 77\%-uk a teljes lakásokban összpontosul, amelyekben átlagosan 4,6 férőhely és 3,2 ágy található. Az Airbnb esetében a férőhely az elszállásolható vendégek számát jelenti, míg az ágyak száma azt, hogy hány darab ágy van az ingatlanban - függetlenül attól, hogy ezek egy- vagy kétszemélyesek. A férőhelyek és az ágyszám külön vizsgálatát az indokolta, hogy az egy-egy szálláshelyre jellemző kínálat szerkezete befolyásolja azt, hogy kik, azaz milyen célcsoport tagjai veszik igénybe legnagyobb eséllyel a szállást.

A meghirdetett Airbnb-szálláshelyek 90\%-a a befogadóképességet tekintve a 6 fó és kevesebb kategóriába sorolható (5. táblázat). A leggyakoribb szállástípus 4 férôhellyel rendelkezik, ami a kínálat 29\%-át adja, míg második helyen a 2 féróhellyel rendelkező szállások találhatók, 26\%-os aránnyal. Ugyanakkor a kínálatban van 87 darab olyan szálláshely is, ami 6-nál több vendég, és ezek közül 42 szálláshely 9-nél több vendég elszállásolására alkalmas.

Az Airbnb alapkoncepciója a kezdetekkor azon alapult, hogy a tulajdonosok felesleges ingatlankapacitásaikat olyan vendégek számára adják bérbe, akiknek szállásra van szükségük. Ez később átalakult, ugyanis a magáncélú hasznosítás mellett egyre inkább előtérbe kerül az ingatlanok befektetési célú megvásárlása (WachsmuthWeisler 2018) és az Airbnb oldalon keresztül annak üzleti célú hasznosítása (Jancsik et al. 2018), a lakások szállodaként való üzemeltetése (Dudás et al. 2017c, Schneiderman 2014), vagyis amikor egy szállásadó a szállásadó oldalon keresztül történő kiadás céljából vásárol vagy bérel ingatlanokat, és egyszerre több ingatlant is hirdet az Airbnb felületén. A nemzetközi szakirodalom az egynél több ingatlant kínáló szállásadókat tekinti „professzionális” üzleti felhasználóknak. A megyei jogú városokban ez a jelenség kevésbé van jelen (6. táblázat), ugyanis a lakások 57\%-át egy szállásadó üzemelteti, szemben például a fővárossal, ahol többségben vannak az üzleti szállásadók, és a lakások több mint felét ők kezelik (Jancsik et al. 2018). Mindemellett az értékelések száma azt is megmutatja, hogy mennyire professzionális szinten folytatják a szállásadók tevékenységüket (Dudás et al. 2017c, Quattrone et al. 2016), ugyanis az értékelések nagy száma magas forgalomra enged következtetni. Az értékelések mennyisége és tartalma fontos a bizalom kialakításában és fenntartásá-

Területi Statisztika, 2018, 58(5): 462-488; DOI: 10.15196/TS580502 
ban, mivel hozzájárul a kedvező imázs megteremtéséhez és megőrzéséhez, ami elősegítheti a korábbi vendégek visszatérését és az új látogatók vonzását (BódisMichalkó 2017, Horváth 2016, Smith et al. 2018).

5. táblázat

Airbnb-szálláshelyek a megyei jogú városokban, a férőhelyek és a fürdőszobák száma alapján, 2018. április

Characteristics of Airbnb accommodations based on the number of available places and bathrooms, April, 2018

\begin{tabular}{|c|c|c|c|c|c|c|c|}
\hline \multicolumn{4}{|c|}{ A férőhelyek száma szerint } & \multicolumn{4}{|c|}{ A fürdőszobák száma szerint } \\
\hline Férőhely & $\begin{array}{c}\text { Szálláshely, } \\
\text { darab }\end{array}$ & $\begin{array}{c}\text { Megoszlás, } \\
\%\end{array}$ & $\begin{array}{c}\text { Átlagos } \\
\text { szállásár, } \\
\text { forint/éjszaka }\end{array}$ & $\begin{array}{c}\text { Fürdőszo- } \\
\text { bák számaa) }\end{array}$ & $\begin{array}{c}\text { Szálláshely, } \\
\text { darab }\end{array}$ & $\begin{array}{c}\text { Megoszlás, } \\
\%\end{array}$ & $\begin{array}{c}\text { Átlagos } \\
\text { szállásár, } \\
\text { forint/éjszaka }\end{array}$ \\
\hline 1 & 23 & 2,58 & 7207 & 1 & 723 & 82,63 & 13015 \\
\hline 2 & 235 & 26,40 & 11769 & 1b) & 57 & 6,51 & 13306 \\
\hline 3 & 104 & 11,69 & 10172 & 2 & 47 & 5,37 & 19805 \\
\hline 4 & 262 & 29,44 & 14232 & 2 b) & 9 & 1,03 & 17546 \\
\hline 5 & 90 & 10,11 & 13422 & 3 & 18 & 2,06 & 18049 \\
\hline 6 & 89 & 10,00 & 17524 & 3 b) & 8 & 0,91 & 9750 \\
\hline 7 & 16 & 1,80 & 13866 & 4 & 3 & 0,34 & 44053 \\
\hline 8 & 27 & 3,03 & 18546 & 4 b) & 1 & 0,11 & 4500 \\
\hline 9 & 2 & 0,22 & 26036 & 5 & 3 & 0,34 & 15381 \\
\hline 10 & 10 & 1,12 & 32131 & 5 b) & - & - & - \\
\hline 11 & 3 & 0,34 & 22267 & $6+$ & 6 & 0,69 & 9633 \\
\hline 12 & 6 & 0,67 & 18450 & & & & \\
\hline 13 & 4 & 0,45 & 35889 & & & & \\
\hline 14 & 2 & 0,22 & 7500 & & & & \\
\hline 15 & 1 & 0,11 & 19243 & & & & \\
\hline 16 & 16 & 1,80 & 7023 & & & & \\
\hline
\end{tabular}

A megyei jogú városokban a vélemények több mint $85 \%$-a a teljes lakásokhoz köthető. Míg ebben a szállástípusban átlagosan 9,96, addig a privát szobáknál átlagosan 4,17 vélemény érkezett a vendégektől (4. táblázat). A vélemények értékeinek határozott különbségei heterogén szórás mellett statisztikai szempontból is szignifikánsak (t: 3,368, sig: 0,000). Mindemellett a vendégek elégedettebbek a teljes lakásokban kapott szolgáltatásokkal, mert kéttizeddel magasabb értékeléseket adtak átlagosan az ott eltöltött vendégéjszakák után. Ezt a független kétmintás t-próba is 
alátámasztotta, hiszen heterogén szórás mellett szignifikánsan (t: 2,625, sig: 0,010) eltért a két csoport átlaga. Fontos azonban kiemelni, hogy míg a teljes lakásoknál a szállásadók fele, addig a privát szobáknál a 70\%-a nem rendelkezik értékeléssel, ami a statisztikai vizsgálatnál a teljes elemszámot 414-re mérsékelte. Ez arra utalhat, hogy a viszonylag „bejáratott” és üzletszerúen üzemeltett szálláshelyeket gyakrabban veszik igénybe. A 6. táblázat adataiból továbbá azt is megtudhatjuk, hogy az egy szállásadó által üzemeltetett ingatlanok számának növekedésével, ha kismértékben is, de csökken az értékelések átlagos értéke, ami arra enged következtetni, hogy minél kevesebb ingatlant üzemeltet valaki, annál jobb minőségű szolgáltatást tud biztosítani, ami a felhasználói elégedettségben is tükröződhet, további megnövekedett keresletet indukálva.

6. táblázat

Airbnb-kínálat a megyei jogú városokban a szállásadók által üzemeltetett ingatlanok száma alapján, 2018. április

Characteristics of Airbnb supply based on the number of properties owned by the host, April 2018

\begin{tabular}{c|c|c|c|c|c}
\hline $\begin{array}{c}\text { Üzemeltett in- } \\
\text { gatlanok száma }\end{array}$ & $\begin{array}{c}\text { Szállásadók } \\
\text { száma }\end{array}$ & $\begin{array}{c}\text { Megoszlás, } \\
\%\end{array}$ & $\begin{array}{c}\text { Átlagos szállásár, } \\
\text { forint/éjszaka }\end{array}$ & $\begin{array}{c}\text { Vélemények } \\
\text { száma }\end{array}$ & $\begin{array}{c}\text { Átlagos } \\
\text { értékelés }\end{array}$ \\
\hline 1 & 510 & 57,30 & 13150 & 4471 & 4,85 \\
2 & 72 & 16,18 & 11466 & 1345 & 4,82 \\
3 & 31 & 10,45 & 12051 & 777 & 4,71 \\
4 & 9 & 4,04 & 13451 & 142 & 4,67 \\
5 & 6 & 3,37 & 9440 & 375 & 4,68 \\
6 & 5 & 3,37 & 39270 & 116 & 4,70 \\
7 & 2 & 1,57 & 7794 & 82 & 4,81 \\
8 & 1 & 0,90 & 9750 & - & - \\
9 & - & - & - & - & - \\
10 & - & - & - & - & - \\
11 & - & - & - & - & - \\
12 & 1 & 1,35 & 20125 & 10 & 3,50 \\
13 & 1 & 1,46 & 15169 & 5 & 5,00
\end{tabular}

Forrás: egyéni adatgyűjtés alapján saját szerkesztés.

\section{Területi eloszlás}

Az adatok elemzéséből megállapítható, hogy az Airbnb-szállások megoszlása a megyei jogú városok között meglehetősen egyenlőtlen (4. ábra), és döntően 4 városban koncentrálódnak. Pécs rendelkezik a legnagyobb kínálattal (170), majd Szeged (157), Eger (126) és Debrecen (104) következik a sorban, Dunaújvárosban (3), Nagykanizsán (2) és Tatabányán (2) az Airbnb jelenléte szinte elhanyagolható. A P2P-

Területi Statisztika, 2018, 58(5): 462-488; DOI: 10.15196/TS580502 
szállásadás tehát elsősorban azokban a megyei jogú városokban emelkedik ki, ahol a kereskedelmiszállás-férőhelyek száma is magas (Bálint-Magyar-Papp 2016), bár ez nem minden város esetében érvényesül, ugyanis Miskolcon az Airbnb-kínálat a meghatározó magán- és kereskedelmi szálláskínálat mellett is mérsékeltnek tekinthető. Az Airbnb napi átlagáraiban is jelentős szóródás figyelhető meg az egyes városoknál, amit a 4. ábra is jól szemléltet, azonban a szállásárak így is döntően a 10-20 ezer forintos sávban mozognak, leszámítva Érdet, ahol 35 ezer forint feletti napi átlagáron foglalhatunk ilyen típusú szállást. E magas átlagárat a kínált szállások alacsony száma magyarázza.

4. ábra

Az Airbnb-szálláshelyek száma és átlagára a megyei jogú városokban, 2018. április

Number and average price of Airbnb accommodations in cities with county rights, April 2018

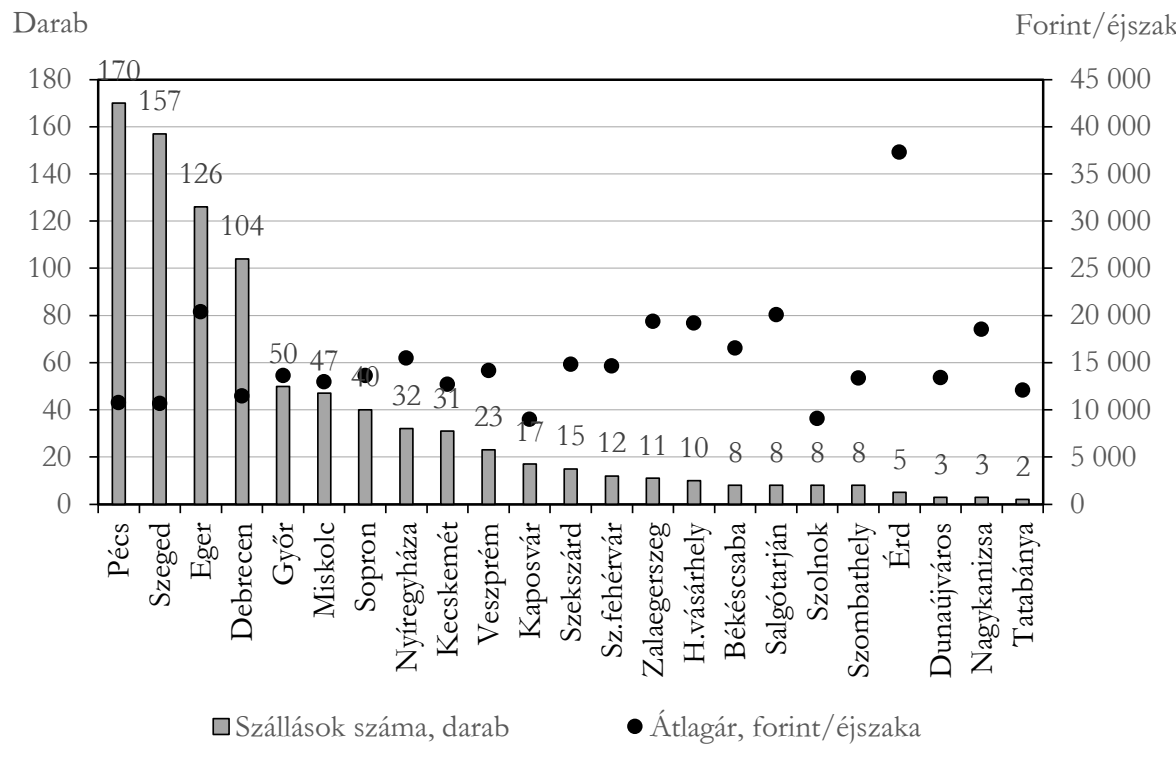

Forrás: egyéni adatgyűjtés alapján saját szerkesztés.

A kutatás során megvizsgáltuk azt is, hogy mennyire jelent versenytársat az Airbnb a hagyományos szálláshelyek számára. Összehasonlítottuk tehát a 4 legjelentősebb Airbnb-potenciállal rendelkező megyei jogú városban (Pécs, Szeged, Eger, Debrecen) az Airbnb-n keresztül kiadott magánszállások átlagárait a KSH által közölt kereskedelmi szálláshelyek - esetünkben a hotelek és panziók - átlagos szállásáraival, valamint a KSH-adatok árnyalása céljából további áradatokat is gyújtöttünk egy online metakereső oldalról (7. táblázat). Az Airbnb esetében külön vizsgáltuk a

Területi Statisztika, 2018, 58(5): 462-488; DOI: 10.15196/TS580502 
teljes lakások, valamint a privát szobák árait annak érdekében, hogy még részletesebben bemutassuk a kiemelt városokban jellemző árviszonyokat.

7. táblázat

A különböző szállástípusok kapacitása és átlagára, 2018. április

Different types of accommodation by capacity and average rates April 2018

\begin{tabular}{|c|c|c|c|c|c|}
\hline \multirow{2}{*}{ Város } & \multicolumn{3}{|c|}{ Airbnb } & \multirow{2}{*}{ Hotel } & \multirow{2}{*}{ Panzió } \\
\hline & Teljes lakás & Privát szoba & Összesena) & & \\
\hline & \multicolumn{5}{|c|}{ Szállásadók száma } \\
\hline Debrecen & 67 & 36 & 104 & 16 & 16 \\
\hline Eger & 82 & 43 & 126 & 18 & 18 \\
\hline Pécs & 127 & 42 & 170 & 21 & 13 \\
\hline \multirow[t]{2}{*}{ Szeged } & 124 & 32 & 157 & 20 & 13 \\
\hline & \multicolumn{5}{|c|}{ Átlagos szállásár, forint/éjszakab) } \\
\hline Debrecen & 12428 & 9804 & 11448 & 17875 & 11136 \\
\hline Eger & 14528 & 31694 & 20366 & 17397 & 10878 \\
\hline Pécs & 11763 & 7922 & 10762 & 11561 & 9506 \\
\hline \multirow[t]{2}{*}{ Szeged } & 10935 & 9838 & 10677 & 15920 & 11262 \\
\hline & \multicolumn{5}{|c|}{ Legolcsóbb szállásár, forint/éjszakac) } \\
\hline Debrecen & 3000 & 2547 & 3000 & 11019 & 7000 \\
\hline Eger & 4000 & 4900 & 4000 & 9969 & 7399 \\
\hline Pécs & 3800 & 2246 & 2246 & 8505 & 6231 \\
\hline \multirow[t]{2}{*}{ Szeged } & 4000 & 3000 & 3000 & 11838 & 7259 \\
\hline & \multicolumn{5}{|c|}{ Legdrágább szállásár, forint/éjszakac) } \\
\hline Debrecen & 160339 & 27900 & 160339 & 40499 & 16823 \\
\hline Eger & 53000 & 150000 & 150000 & 31923 & 15950 \\
\hline Pécs & 123635 & 23800 & 123635 & 26480 & 20561 \\
\hline \multirow[t]{2}{*}{ Szeged } & 41693 & 22089 & 41693 & 43178 & 17134 \\
\hline & \multicolumn{5}{|c|}{ Az 5 legolcsóbb szállás átlagára, forint/éjszakac) } \\
\hline Debrecen & 3384 & 3109 & 2849 & 13291 & 9217 \\
\hline Eger & 4720 & 5632 & 4656 & 12754 & 9279 \\
\hline Pécs & 4340 & 3098 & 3088 & 11779 & 9001 \\
\hline Szeged & 4587 & 4079 & 3817 & 14907 & 8067 \\
\hline
\end{tabular}

A legnagyobb Airbnb-kínálatot felvonultató 4 városban az oldalon feltüntetett árakat tekintve 3 város (Debrecen, Pécs, Szeged) hasonló pályán mozog, míg Egernél teljesen eltérő tendenciák figyelhetők meg. Az eredmények jól mutatják, hogy az előbbi városok esetében az Airbnb-átlagárak 10-11 ezer forint körüliek, valamint a

Területi Statisztika, 2018, 58(5): 462-488; DOI: 10.15196/TS580502 
teljes lakások napi átlagára magasabb, mint a privát szobáké. Ezzel szemben Egerben az Airbnb-átlagár 20 ezer forint körül mozog, továbbá a privát szobák foglalása duplájába kerül a teljes lakásokénak. Ez részben arra vezethetô vissza, hogy Egerben a másik 3 városénál is erősebb a turisztikai szektor szerepe, ugyanis több „professzionális" Airbnb-szállásadó is megtalálható a városban. Ezek magas szintú szolgáltatásokat nyújtó, magasabb árfekvésú ingatlanokat kínálnak rövid távú szállásként az oldalon, aminek köszönhetően e szállások átlagára is magasabb. Mindemellett a turizmus jelentőségét az is mutatja, hogy Egerben az ezer lakosra jutó kereskedelmi férőhelyek száma 75, addig a másik 3 városban 20-30 körüli, de hasonlóak a trendek az ezer lakosra jutó Airbnb-férőhelyek számát tekintve is. Így az említett 3 városban az Airbnb-szállásárak meghatározásánál inkább az egyetemváros funkció és az ahhoz kapcsolódó kereslet a meghatározó, így esetükben magasabb az alacsonyabb árfekvésú, rövid távú szállások száma. Az egyes szállástípusok napi átlagárait összehasonlítva megállapítható, hogy az Airbnb árai a panziók által kínált árszínvonalon mozognak (kivéve Eger), így a legtöbb esetben olcsóbbak és versenyképesebbek a hotelek által kínált szállásáraknál, és ezzel az olcsóbb árral vélhetően ellensúlyozni tudják a hotelek által nyújtott többletszolgáltatásokat, mint amilyen például a 24 órás recepciós szolgálat, étterem, parkoló vagy bizonyos szállodák esetén a fitnesz- és wellness szolgáltatások.

Ha az átlagárak mellett összehasonlítjuk az egyes városokban a különböző szállástípusok legolcsóbb és legdrágább szállásárait, figyelemre méltó különbségek rajzolódnak ki. A legolcsóbb szállásáraknál az Airbnb mind a teljes lakásoknál, mind a privát szobáknál nemcsak a hotelszobák, de a panziók árainál is olcsóbb szállásárakat kínál. Hasonló tendencia figyelhető meg, ha az 5 legolcsóbb szállásárat vesszük figyelembe az egyes városokban, ugyanis az Airbnb sokkal versenyképesebb árakat tud kínálni a kereskedelmi szállásadókkal szemben. Ellenben a legdrágább szállásárak tekintetében az Airbnb kiemelkedik, viszont ennek fejében olyan plusz szolgáltatásokat kínál az egyes szállásokon, amelyek a szállodák és a panziók kínálatából hiányoznak.

\section{Összefoglalás}

Kutatásunkban a rövid távú szállásszolgáltatás (Airbnb) helyzetét elemeztük a megyei jogú városokban, összehasonlítva a kereskedelmi szálláshelyek kínálatával. Eredményeink azt mutatják, hogy az Airbnb döntően nagyvárosi jelenség, valamint a jelentôs turisztikai vonzerôvel és potenciállal rendelkezô városokban, térségekben terjedt el (Adamiak 2018). Magyarországon a megyei jogú városokban is jelen van az Airbnb, ugyanakkor mind a kínált szállások számát, mind az ezer lakosra jutó Airbnb-szálláshelyek számát tekintve jelentősen elmarad a budapesti kínálattól. Azaz a P2P-szállásadás nagyvárosi jellege továbbra is meghatározó, ugyanakkor jelentős különbségekkel.

Területi Statisztika, 2018, 58(5): 462-488; DOI: 10.15196/TS580502 
Az eredményeket összegezve megállapítható, hogy az Airbnb-kínálat a vizsgált városokban illeszkedik a nemzetközi (Abdar-Yen 2017) és a budapesti trendekhez (Boros et al. 2018, Jancsik et al. 2018), így a kínálatban a teljes lakások vannak többségben, és a közös szobák aránya elhanyagolható. A megyei jogú városok között az Airbnb-szállások számát tekintve 4 város emelkedik ki (Pécs, Szeged, Eger, Debrecen), azonban az eredményeink azt mutatják, hogy nem jelenthető ki egyértelmúen, hogy az Airbnb szerepe azokban a városokban meghatározó, amelyek eleve jelentősebb kereskedelmiszálláshely-kapacitással és -forgalommal rendelkeznek, illetve a településméret sem tekinthető meghatározó tényezőnek.

Vizsgálatunk azt is megerősítette, hogy az Airbnb által kínált szállásárak versenyképesek a kereskedelmi szálláshelyek áraival. Az Airbnb-n kínált szállások hasonló árszínvonalon mozognak, mint a panziók árai, és sokkal versenyképesebbek, mint a hotelek árai, ami arra enged következtetni, hogy az olcsóbb árak ellensúlyozzák azoknak a szolgáltatásoknak a hiányát, amelyek a hotelek esetében a vendégek rendelkezésére állnak. A kutatás azt is jól körvonalazza, hogy az Airbnb esetében is érvényesülhet a közösségi gazdaság, a helyi társadalmi folyamatok befolyásoló hatása, hiszen a jelentős turisztikai vonzerővel rendelkezó Egerben sokkal magasabb áron foglalhatók a szállások, mint a hasonló számú Airbnb-szállással rendelkező Pécsett, Szegeden vagy Debrecenben.

Az adatgyújtés jövőbeni szisztematikus megismétlésével további kutatás tárgyát képezheti az Airbnb terjedésének figyelemmel kísérése, valamint a vizsgálat kiterjesztése más hazai, nemzetközi (turisztikai) régióra és desztinációra is, ami széles körű összehasonlítást biztosítana. A településhierarchián belüli térnyerés mellett lehetôvé tenné a következő kérdések elemzését is: (1) hogyan jelenik meg a kisebb városokban a P2P-szállásadás, (2) az Airbnb helyi hatásai mennyiben különböznek a nagyvárosokban megfigyeltektől, (3) mi befolyásolja az Airbnb megjelenését a különböző országok alacsonyabb településhierarchia-szintjein? Ehhez kapcsolódóan érdemes lenne mélyebben megvizsgálni az Airbnb-nek a hotelekre és az adott települések ingatlanpiacára gyakorolt hatásait is, továbbá azokat összehasonlítani a nemzetközi trendekkel.

\section{Köszönetnyilvánítás}

A tanulmányban ismertetett kutatás a 128015 számú „A magyarországi közösségi szállásadás földrajzi vizsgálata" projekt részeként, a Nemzeti Kutatási Fejlesztési és Innovációs Alap támogatásával valósult meg.

\section{IRODALOM}

ABDAR, M. -YEN, N. Y. (2017): Understanding regional characteristics through crowd preference and confidence mining in P2P accommodation rental service Library Hi Tech 35 (4): 521-541. https://doi.org/10.1108/lht-01-2017-0030

Területi Statisztika, 2018, 58(5): 462-488; DOI: 10.15196/TS580502 
AdamiaK, C. (2018): Mapping Airbnb supply in European cities Annals of Tourism Research 71 (C): 67-71. https://doi.org/10.1016/j.annals.2018.02.008

BÁLINT, D.-MAGYAR-PAPP, J. (2016): Megosztáson alapuló gazdaság a turizmus szektorban: Esettanulmány Pécsről. In: PAjTóKNÉ TARI, I. (szerk.) Magyar Földrajzi Napok 2016 pp. 676-686., Eszterházy Károly Egyetem, Magyar Földrajzi Társaság, Agria Geografia Alapítvány, Eger.

BÁlint, D.-TRóCSÁNYI, A. (2016): New ways of mobility: the birth of ridesharing. A case study from Hungary Hungarian Geographical Bulletin 65 (4): 391-405. https://doi.org/10.15201/hungeobull.65.4.7

BÓDIS G.-MiCHALKÓ, G. (2017) Jöttünk, láttunk visszatérünk: a visszatérô turisztikai forgalom. Területi Statisztika 57 (3): 294-310. https://doi.org/10.15196/ts570303

Boros, L.-DudÁs, G. (2017): A közösségi szállásadás konfliktusai és dilemmái Földrajzi Közlemények 141 (3): 288-298.

Boros, L.-DudÁs, G.-KOvAlcsiK, T.-PAPP, S.-VIDA, GY. (2018): Airbnb in Budapest: Analysing spatial patterns and room rates of hotels and peer-to-peer accommodations GeoJournal of Tourism and Geosites 21 (1): 26-38.

Boros, L.-DudÁs, G.-PÁL, V. (2016): Webes adatgyűjtés lehetőségei az Airbnb vizsgálatában In: Varga, Á. (szerk.) Földrajzi Információs Rendszerek gyakorlati alkalmazása pp. 93-105., Budapesti Corvinus Egyetem, Budapest.

Botsman, R.-Rogers, R. (2011): What's mine is yours New York: Harper Business.

BUCHER, E.-FIESELER, C.-LUTZ, C. (2016): What's mine is yours (for a nominal fee) - Exploring the spectrum of utilitarian to altruistic motives for Internet-mediated sharing Computers in Human Behaviour 62: 316-326. https://doi.org/10.1016 /j.chb.2016.04.002

BuDA, G.-LEHOTA, J. (2017): Az internetalapú közösségi gazdálkodás formái Gazdaság és Társadalom 9 (2): 23-46. https://doi.org/10.21637/gt.2017.2.02.

CHOI, K-H.-Jung, J.-RYU, S.-KIM, S-D.-YOON, S-M. (2015): The relationship between Airbnb and the Hotel Revenue: In the Case of Korea Indian Journal of Science and Technology 8 (26): 1-8. https://doi.org/10.17485/ijst/2015/v8i26/81013

Dudás, G.-Boros, L.-KovalcsiK, T.-KovalcsiK, B. (2017a): Az Airbnb térbeliségének vizsgálata raszteres adatábrázolási technika alkalmazásával In: BALÁZs, B. (szerk.) Az elmélet és gyakorlat találkozása a térinformatikában pp. 97-104., Debreceni Egyetemi Kiadó, Debrecen.

DudÁs, G.-Boros, L.-KovalcsiK, T.-KovalcsiK, B. (2017b): The visualisation of the spatiality of Airbnb in Budapest using 3-band raster representation Geographica Technica 12 (1): 23-30. https://doi.org/10.21163/gt_2017.121.03

DudÁs, G.-Boros, L.-PÁL, V. (2016): Közösségi szállásadás Budapesten - Az Airbnb térnyerése Településföldrajzi Tanulmányok 5 (3-4): 66-83.

DudÁs, G.-VIDA, GY.-KovalcsiK, T.-BOROS, L. (2017c): A socio-economic analysis of Airbnb in New York City Regional Statistics 7 (1): 135-151. https://doi.org/10.15196/rs07108

Edelman, B.-LucA, M.-Svirsky, D. (2017): Racial Discrimination in the Sharing Economy - Evidence from a Field Experiment America Economic Journal: Applied Economics 9 (2): 1-22. https://doi.org/10.1257/app.20160213

Területi Statisztika, 2018, 58(5): 462-488; DOI: 10.15196/TS580502 
ERT, E.-Fleischer, A.-MAGEN, N. (2016): Trust and reputation in the sharing economy: The role of personal photos in Airbnb Tourism Management 55: 62-73. https://doi.org/10.1016/j.tourman.2016.01.013

FANG, B.-YE, Q.-LAW, R. (2016): Effect of Sharing Economy on Tourism Industry Employment Annals of Tourism Research 57: 264-267. https://doi.org /10.1016/j.annals.2015.11.018

Frenken, K. (2017): Political economies and environmental futures for the sharing economy Philosophical Transactions of the Royal Society A, 375: 20160367. https://doi.org/10.1098/rsta.2016.0367

FRENKEN, K.-SCHOR, J. (2017): Putting the sharing economy into perspective Environmental Innovations and Societal Transitions 23: 3-10. https://doi.org/10.1016/ j.eist.2017.01.003

GANSKY, L. (2010): The mesh: Why the future of business is sharing Penguin.

GibBs, C.-Guttentag, D.-Gretzel, U.-Morton, J.-Goodwill, A. (2017): Pricing in the sharing economy: a hedonic pricing model applied to Airbnb listings Journal of Travel \& Tourism Marketing 35 (1): 46-56. https://doi.org /10.1080/10548408.2017.1308292

GunTER, U. -ÖNDER, I. (2017): Determinants of Airbnb demand in Vienna and their implications for the traditional accommodation industry Tourism Economics 24 (3): 270-293. https://doi.org/10.1177/1354816617731196

Gutiérrez，J.-García-Palomares，J. C.-Romanillos，G.-SAlas-Olmedo， M. H. (2017): The eruption of Airbnb in tourist cities: Comparing spatial patterns of hotels and peer-to-peer accommodation in Barcelona Tourism Management 62: 278-291. https://doi.org/10.1016/j.tourman.2017.05.003

GutTentag, D. (2013): Airbnb: Disruptive Innovation and the Rise of an Informal Tourism Accommodation Sector Current Issues in Tourism 18 (12): 1192-1217. https://doi.org/10.1080/13683500.2013.827159

GutTentag, D.-Smith, S. (2017): Assessing Airbnb as a disruptive innovation relative to hotels: Substitution and comparative performance expectations International Journal of Hospitality Management 64: 1-10. https://doi.org/10.1016 /j.ijhm.2017.02.003

GutTentag, D.-Smith, S.-PotwarkA, L.-Havitz, M. (2017): Why Tourist Choose Airbnb: A Motivation-Based Segmentation Study Journal of Travel Research 57 (3): 342-359. https://doi.org/10.1177/0047287517696980

GYÓDI, K. (2018): Airbnb and the hotel industry in Warsaw: An example of the sharing economy? Central European Economic Journal 2 (49): 23-34. https://doi.org /10.1515/ceej-2017-0007

HAJIBABA, H.-DOLNICAR, S. (2017): Regulatory Reactions Around the World In: DOLNICAR, S. (ed.) Peer-to-Peer Accommodation Networks pp. 120-136., Goodfellow Publishers, Oxford. https://doi.org/10.23912/9781911396512-3609

HORN, K.-MERAnTE, M. (2017): Is home sharing driving up rents? Evidence from Airbnb in Boston Journal of Housing Economics 38: 14-24. https://doi.org /10.1016/j.jhe.2017.08.002

HoRvÁTH, E. Zs. (2016): Assessing the regional impact based on destination image. Regional Statistics 6 (1): 164-192. https://doi.org/10.15196/RS06109

Területi Statisztika, 2018, 58(5): 462-488; DOI: 10.15196/TS580502 
JanCSIK, A.-MichalKó, G.-CSERnYIK, M. (2018): Megosztás megosztottság nélkül - az Airbnb és a budapesti szálláshelypiac átalakulása Közgazdasági Szemle 65 (3): 259-286. https://doi.org/10.18414/ksz.2018.3.259

JefFerson-JONES, J. (2015): Airbnb and the Housing Segment of the Modern "Sharing Economy": Are Short-Term Rental Restrictions an Unconstitutional Taking? Hastings Constitutional Law Quaterly 42: 557-575.

Jung, J.-Yoon, S.-KIM, S.-PARK, S.-LEE, K-P.-LEE, U. (2016): Social or financial goals? Comparative analysis of user behaviours in couchsurfing and Airbnb Proceedings of the 2016 ACM Conference on Human Factors in Computing Systems: 2857-2863.

KAPLAN, R. A.-NADLER, M. L. (2015): Airbnb: a case study in occupancy regulation and taxation The University of Chicago Law Review Dialogue 82 (1): 103-105.

Karakasné Morvay, K. (2017): Satisfaction and Characteristics of Airbnb demand in Budapest Zbornik Radova Departmana Za Geografiju Turizam I Hotelijertsvo 42 (2): 76-88.

KARLSSON, L.-DOLNICAR, S. (2016): Someone's been sleeping in my bed Annals of Tourism Research 58: 159-162. https://doi.org/10.1016/j.annals.2016.02.006

KE, Q. (2017): Sharing Means Renting?: An Entire-marketplace Analysis of Airbnb Proceedings of the 2017 ACM on Web Science Conference (2017): 131-139. https://doi.org/10.2139/ssrn.2902840

KLJUCNIKOV, A. -KRAJCIK, V. -VICNÚROVÁ, Z. (2018): International sharing economy: the case of Airbnb in the Czech Republic Economics and Sociology 11 (2): 126-137.

Malhotra, A.-VAn Alstyne, M. (2014): The dark side of the sharing economy ... and how to lighten it Communication of the ACM 57 (11): 24-27. https://doi.org/10.1145/2668893

Matzler, K.-Veider, V.-Kathan, W. (2015): Adapting to the Sharing Economy MITSloan Management Review 56 (2): 70-77.

M. BARNA, K.-PAPP, Zs. (2017): Az idegenforgalmi adó volumenének és felhasználásának területi különbségei, 2000-2013 Területi Statisztika 57 82): 224-243. https://doi.org/10.15196/ts570206

Möhlmann, M. (2015): Collaborative consumption: determinants of satisfaction and the likelihood of using a sharing economy option again Journal of Consumer Behaviour 14 (3): 193-207. https:/ / doi.org/10.1002/cb.1512

Munoz, P.-COHEN, B. (2017): Mapping out the sharing economy: A configurational approach to sharing business modeling Technological Forecasting \& Social Change 125: 21-37. https://doi.org/10.1016/j.techfore.2017.03.035

Murillo, D.-BuCKLAND, H.-VAL, E. (2017): When the sharing economy becomes neoliberalism on steroids: Unravelling the controversies Technological Forecasting \& Social Change 125: 66-76. https:/ / doi.org/10.1016/j.techfore.2017.05.024

Olmedilla, M.-Martínez-Torres, M. R.-Toral, S. L. (2016): Harvesting Big Data in social science: A methodological approach for collecting online user-generated content Computer Standards \& Interfaces 46: 79-87. https://doi.org/10.1016 /j.csi.2016.02.003

OSKAM, J.-BOSWIJK, A. (2016): Airbnb: the future of networked hospitality businesses Journal of Tourism Futures 2 (1): 22-42 https:/ / doi.org/10.1108/jtf-11-2015-0048

Területi Statisztika, 2018, 58(5): 462-488; DOI: 10.15196/TS580502 
PÁsZTor, M.-UgrósDy, GY.-VILLÁNYI, J. (2017): A fogyasztói árstatisztika gyűjtésének módjai. In: LEHOTA, J. (szerk.) Életem a felsóoktatásban: Dr. Molnár József 70 éves pp. 37-43., Szent István Egyetem Kiadó, Gödöllő.

PIZAM, A. (2014): Peer-to-peer travel: Blessing or blight? International Journal of Hospitality Management 38: 118-119. https://doi.org/10.1016/j.ijhm.2014.02.013

Quattrone, G.-Proserpio, D.-Quercia, D.-CAPrA, L.-Musolesi, M. (2016): Who benefits from the "sharing" economy of Airbnb? Proceedings of the $25^{\text {th }}$ International Conference on World Wide Web, 1385-1394. https://doi.org/10.1145 $/ 2872427.2874815$

RANCHORDÁs, S.-ZuREK, K.-GEDEON, Zs. (2016): Home-Sharing in the Digital Economy: The cases of Brussels, Stockholm and Budapest Impulse Paper prepared for the European Commission.

Smith, M. -Egedy, T. - Csizmady, A. - JAncsik, A. -Olt, G. -Michalkó, G. (2017): Non-planning and tourism consumption in Budapest's inner city Tourism Geographies 20: 524-548. https://doi.org/10.1080/14616688.2017.1387809

SMITH, M. -SulyOK, J. -JANCSIK, A. -PuCZKÓ, L. -KISS, K. -SZIVA, I. -PAPP-VÁRY, A.F. MichalKó, G. (2018): Nomen est omen - Tourist image of the Balkans. Hungarian Geographical Bulletin 67 (2): 173-188. https://doi.org/10.15201 / hungeobull.67.2.5

Stephany, A. (2015): The Business of Sharing - Making in the New Sharing Economy. Palgrave MacMillan, New York. https://doi.org/10.1057/9781137376183

Teubner, T.-Hawlitschek, F.-Dann, D. (2017): Price determinants on Airbnb: How reputation pays off in the sharing economy Journal of Self-Governance and Management Economics 5 (4): 53-80. https://doi.org/10.22381/jsme5420173

TEubner, T.-SAADE, N.-HAWLITSCHEK, F-WEINHARDT, C. (2016): It's only pixels, badges, and stars: On the economic value of reputation on Airbnb Australasian Conference on Information Systems, Wollongong, Australia.

Tussyadiah I. P. (2015): An Exploratory Study on Drivers and Deterrents of Collaborative Consumption in Travel. In: Tussyadiah, I. P.-InVERsini A. (eds.) Information and Communication Technologies in Tourism 2015 pp. 817-830., Springer International Publishing, Switzerland. https://doi.org /10.1007/978-3-319-14343-9_59

Tussyadiah, I. P.-Pesonen, J. (2016): Impacts of Peer-to-Peer Accommodation Use on Travel Patterns Journal of Travel Research 55 (8): 1022-1040. https://doi.org /10.1177/0047287515608505

Wachsmuth, D.-Chaney, D.-Kerrigan, D.-Shillolo, A.-Basalaev-Binder, R. (2018): The High-Cost of Short-Term Rentals In New York City School of urban Planning, Mc Gill University.

Wachsmuth, D.-Weisler, A. (2018): Airbnb and the rent gap: Gentrification through the sharing economy Environment and Planning A: 1-24. https://doi.org $/ 10.1177 / 0308518 \times 18778038$

Wegmann, J.-JiaO, J. (2017): Taming Airbnb: Toward guiding principles for local regulation of urban vacation rentals based on empirical results from five US cities Land use Policy 69: 494-501. https://doi.org/10.1016/j.landusepol.2017.09.025

Területi Statisztika, 2018, 58(5): 462-488; DOI: 10.15196/TS580502 
XIE, K. L.-KWOK, L. (2017): The effects of Airbnb's price positioning on hotel performance International Journal of Hospitality Management 67: 174-184. https://doi.org /10.1016/j.ijhm.2017.08.011

Zervas, G.-Proserpio, D.-Byers, J. (2017): The Rise of the Sharing Economy: Estimating the Impact of Airbnb on the Hotel Industry Journal of Marketing Research 54 (5): 687-705. https://doi.org/10.1509/jmr.15.0204

\section{INTERNETES HIVATKOZÁSOK}

239/2009. (X. 20.) Korm. rendelet: A szálláshely-szolgáltatási tevékenység folytatásának részletes feltétetleiről és a szálláshely-üzemeltetési engedély kiadásának rendjérôl http:/ / www.kozlonyok.hu/nkonline/index.php?menuindex $=200 \&$ pageindex $=\mathrm{k}$ ozltart\&ev $=2009 \&$ szam $=148$

AIRBNB (2018): Fast facts Letöltve: https:/ / press.atairbnb.com/fast-facts/

Alvarado, C.-Hennis, S.-HaYwood, J. (2016): STR: Airbnb's impact on NYC's boroughs Hotel News Now Letöltve: http://www.hotelnewsnow.com/Articles/ 30455/STR-Airbnbs-impact-on-NYCs-boroughs

Botsman, R. (2015): Defining the sharing economy: What is Collaborative Consumption And What isn't? Fastcompany Letöltve: https://www.fastcompany.com /3046119/defining-the-sharing-economy-what-is-collaborative-consumptionand-what-isnt

Corsun, D. L.-XIE, K. L.-Young, C. A. (2016): Short-term rental in Denver, CO Letöltve: www.cpr.org/sites/default/files/du-short-term-rental.pdf

Cox, M. (2017): The face of Airbnb, New York City - Airbnb as a Racial Gentrification Tool Letöltve: http://brooklyndeep.org/wp-content/uploads/2017/03/theface-of-airbnb-nyc.pdf

Cox, M.-SleE, T. (2016): How Airbnb's data hid the facts in New York City Letöltve: http://insideairbnb.com/reports/how-airbnbs-data-hid-the-facts-in-new-yorkcity.pdf

Delgado-Medrano, H. M.-LyOn, K. (2016): Short Changing New York City - The impact of Airbnb on New York City's housing market BJH Advisors LLC Letöltve: file:///C:/Users/dudasgabor/Desktop/Munka/Delgado-Medrano,\%20Lyon $\% 202016 \% 20-\% 20$ Short $\% 20$ Changing $\% 20$ New $\% 20$ York $\% 20$ City $\% 20 \_\% 20$ The $\% 20$ impact $\% 20$ of $\% 20$ Airbnb $\% 20$ on $\% 20$ New $\% 20$ York $\% 20$ City's $\% 20$ housi ng\% $\%$ market $\% 20 . p d f$

Goudin, P. (2016): The Cost of Non-Europe in the Sharing Economy - Economic, Social and Legal Challenges and Opportunities. European Parliament, January 2016. Letöltve: http://www.europarl.europa.eu/RegData/etudes/STUD/2016/ 558777/EPRS_STU(2016)558777_EN.pdf

Gutt, D.-Hermann, P. (2015): Sharing Means Caring? Hosts' Price Reaction to Rating Visibility ECIS 2015 Research-in-Progress Papers (Paper 54) Letöltve: https://aisel.aisnet.org/ecis2015_rip/54

HAYWOOD, J.-HOYT, A.-WILsOn, C.-HENNIS, S.-Alvarado, C. (2016): STR: Airbnb's impact minor on Manhattan hotels Hotel News Now Letöltve:

Területi Statisztika, 2018, 58(5): 462-488; DOI: 10.15196/TS580502 
http:/ /www.hotelnewsnow.com/Articles/29639/STR-Airbnbs-impact-minoron-Manhattan-hotels

HVS (2015): Airbnb and Impacts on the New York City Lodging Market and Economy Letöltve: http://www.hanyc.org/wp-content/uploads/2015/10/HVS-ImpactStudy-FINAL-Airbnb-and-the-NYC-Lodging-Market-10-27-15-copy.pdf

KAKAR, V.-Franco, J.-Voelz, J.-Wu, J. (2016): Effects of Host Race Information on Airbnb Listing Prices in San Francisco MPRA Paper No. 69974 Letöltve: https://mpra.ub.uni-muenchen.de/69974/

LANE, J.-WoOdworTH, R. M. (2016): The Sharing Economy Checks In: An Analysis of Airbnb Demand in the United States CBRE Letöltve: http://rss.hsyndicate.com / file/152006083.pdf

MSZÉSZ - MAGYAR SZÁLLODÁK ÉS ÉTTTERMEK SZÖVETSÉGE (2015): A közösségi gazdaság - Sharing Economy - Shadow Economy - megjelenése Magyarországon a kereskedelmi szálláshelyek piacán, s annak hatásai. Letöltve: www.hah.hu/files/9414/4231/9735/A_KZSSGI_GAZDASG_MEGJELENSE _MAGYARORSZGON_A_KERESKEDELMI_SZLLSHELYEK_PIACN_fin al.pdf

NeEsER, D. (2015): Does Airbnb hurt hotel business: Evidence from the Nordic Countries. Master's Thesis. Universidad Carlos III de Madrid, Madrid, Spain Letöltve: https://www.heartland.org/publications-resources/publications/does-airbnbhurt-hotel-business-evidence-from-the-nordic-countries

Nowak, B.-Allen, T.-Rollo, J.-Lewis, V.-He, L.-Chenn, A.-Wilson, W. N.Constantini, M.-HYDE, O.-LiU, K.-SAVInO, M.-Chaudhry, B.A .-Grube, A. M.-Young, E. (2015): Global Insight: Who Will Hurt More - Hotels or OTAs? Morgan Stanley Research Letöltve: http://linkback.morganstanley.com /web/sendlink/webapp/f/9lf3j168-3pcc-g01h-b8bf-

005056013100 ? store $=0 \& d=$ UwBSZXNIYXJjaF9NUwBiNjVjYzAyNi04NGQ2 LTExZTUtYjFIMi03YzhmYTAzZWU4ZjQ\%3D\&user=bdvpwh9kcvqs49\&_gda_=1573813969_cf5a3761794d8651f8618fc7a544cb82.

PluHÁR G. (2017): Informatikai értelmezó szótár. Letöltve: http://mek.oszk.hu /00000/00083/00083.htm.

PWC - PRICEWATERHOUSECOOPERS (2015): Osztogatnak vagy fosztogatnak? A sharing economy térnyerése Letöltve: https://www.pwc.com/hu/hu/kiadvanyok/ assets/pdf/sharing_economy.pdf

SamaAn, R. (2015): Airbnb, rising rent, and the housing crisis in Los Angeles. Letöltve: http://www.laane.org/wp-content/uploads/2015/03/AirBnB-Final.pdf

SABATINI, J. (2015): Airbnb rentals cut deep into SF housing stock, report says SF Examiner Letöltve: https://archives.sfexaminer.com/sanfrancisco/sf-report-says-unitsrented-for-short-term-reduce-long-term-housing/Content?oid=2929888

SCHNEIDERMAN, E. T. (2014): Airbnb in the city Letöltve: https://ag.ny.gov/pdfs/ AIRBNB\%20REPORT.pdf

SCHOR, J. (2014): Debating the sharing economy. Letöltve: http://greattransition.org /publication/debating-the-sharing-economy

SundararajAN, A. (2014): Peer-to-peer businesses and the sharing (collaborative) economy: Overview, economic effects and regulatory issues. Written testimony for the

Területi Statisztika, 2018, 58(5): 462-488; DOI: 10.15196/TS580502 
hearing titled The Power of Connection: Peer to Peer Businesses. Letöltve: https://smallbusiness.house.gov/uploadedfiles/1-15-

2014_revised_sundararajan_testimony.pdf

WATERS, T.-BACH, V. (2016): Making the rent 2016 - Tenant conditions in New York City's changing neighbourhoods Community Service Society - Fighting Poverty Strengthening New York Letöltve: http://lghttp.58547.nexcesscdn.net /803F44A/images/nycss/images/uploads/pubs/Making\%20the $\% 20$ Rent $\% 202$ 016\%20-\%20Final\%20as\%20of\%205\%2012\%2016\%20-\%20web.pdf

Zervas, G.-Proserpio, D.-BYers, J. (2015): A first look at online reputation on Airbnb, where every stay is above average (January 28, 2015). Letöltve: http://papers.ssrn.com/sol3/papers.cfm?abstract_id $=2554500$

HONLAPOK

statinfo.ksh.hu

www.airbnb.com

www.airdna.co

www.trivago.hu 